\title{
Water quality and treatment of river bank filtrate
}

\author{
W. W. J. M. de Vet ${ }^{1,2,3}$, C. C. A. van Genuchten ${ }^{2}$, M. C. M. van Loosdrecht ${ }^{1}$, and J. C. van Dijk ${ }^{3}$ \\ ${ }^{1}$ Dept. of Biotechnology, Delft Univ. of Technology, Julianalaan 67, 2628 BC Delft, The Netherlands \\ ${ }^{2}$ Oasen Drinking Water Company, P.O. Box 122, 2800 AC Gouda, The Netherlands \\ ${ }^{3}$ Dept. of Water Management, Delft Univ. of Technology, Stevinweg 1, 2628 CN Delft, The Netherlands
}

Received: 19 July 2009 - Published in Drink. Water Eng. Sci. Discuss.: 6 October 2009 Revised: 25 February 2010 - Accepted: 17 May 2010 - Published: 17 June 2010

\begin{abstract}
In drinking water production, river bank filtration has the advantages of dampening peak concentrations of many dissolved components, substantially removing many micropollutants and removing, virtually completely, the pathogens and suspended solids. The production aquifer is not only fed by the river bank infiltrate but also by water percolating through covering layers. In the polder areas, these top layers consist of peat and deposits from river sediments and sea intrusions.

This paper discusses the origin and fate of macro components in river bank filtrate, based on extensive full-scale measurements in well fields and treatment systems of the Drinking Water Company Oasen in the Netherlands. First, it clarifies and illustrates redox reactions and the mixing of river bank filtrate and PW as the dominant processes determining the raw water quality for drinking water production. Next, full-scale results are elaborated on to evaluate trickling filtration as an efficient and proven one-step process to remove methane, iron, ammonium and manganese. The interaction of methane and manganese removal with nitrification in these systems is further analyzed. Methane is mostly stripped during trickling filtration and its removal hardly interferes with nitrification. Under specific conditions, microbial manganese removal may play a dominant role.
\end{abstract}

\section{Abbreviations and notations \\ $\mathrm{PW}=$ Polder water \\ $\mathrm{RBF}=$ River bank filtration \\ WTP $=$ Water treatment plant}

\section{Introduction}

Although the role of surface water as a source for drinking water is gradually increasing, in the Netherlands still over $60 \%$ is produced from groundwater (VEWIN, 2008). Groundwater generally has the advantage of a good hygienic and consistent quality compared to surface water. Groundwater abstraction may, however, be restricted especially in areas with desiccation or sea water intrusion. In these cases natural or artificial recharge of the groundwater with surface water may provide a solution, like with dune infiltration and river bank filtration (RBF). Based on the definition of at least

Correspondence to: W. W. J. M. de Vet (w.w.j.m.devet@tudelft.nl)
$10 \%$ infiltrated surface water, the share of river groundwater in the Netherlands in 2007 was 62 millions $\mathrm{m}^{3}, 5 \%$ of the total abstracted amount for drinking water production (VEWIN, 2008). Depending on the hydrological situation, the river may infiltrate or drain the surrounding land. In all cases, abstraction of river bank filtrate enhances the infiltration of river water compared to the natural situation.

Although water from a properly designed RBF plant has the general advantages of groundwater, there are some drawbacks. First of all, persistent micropollutants present in the river water will eventually reach the production wells, although high concentrations are effectively reduced by adsorption, biological breakdown and residence time variation (Sontheimer, 1991). The latter applies to peak concentrations in the river water, which are reduced in the well by blending with earlier and later infiltrated water containing lower micro pollutant concentrations. These remaining substances will have to be removed by specific techniques in the treatment plant. In the Netherlands, all treatment plants for river bank filtrate include advanced oxidation, adsorption and/or membrane filtration steps, which will not be discussed in this paper. 

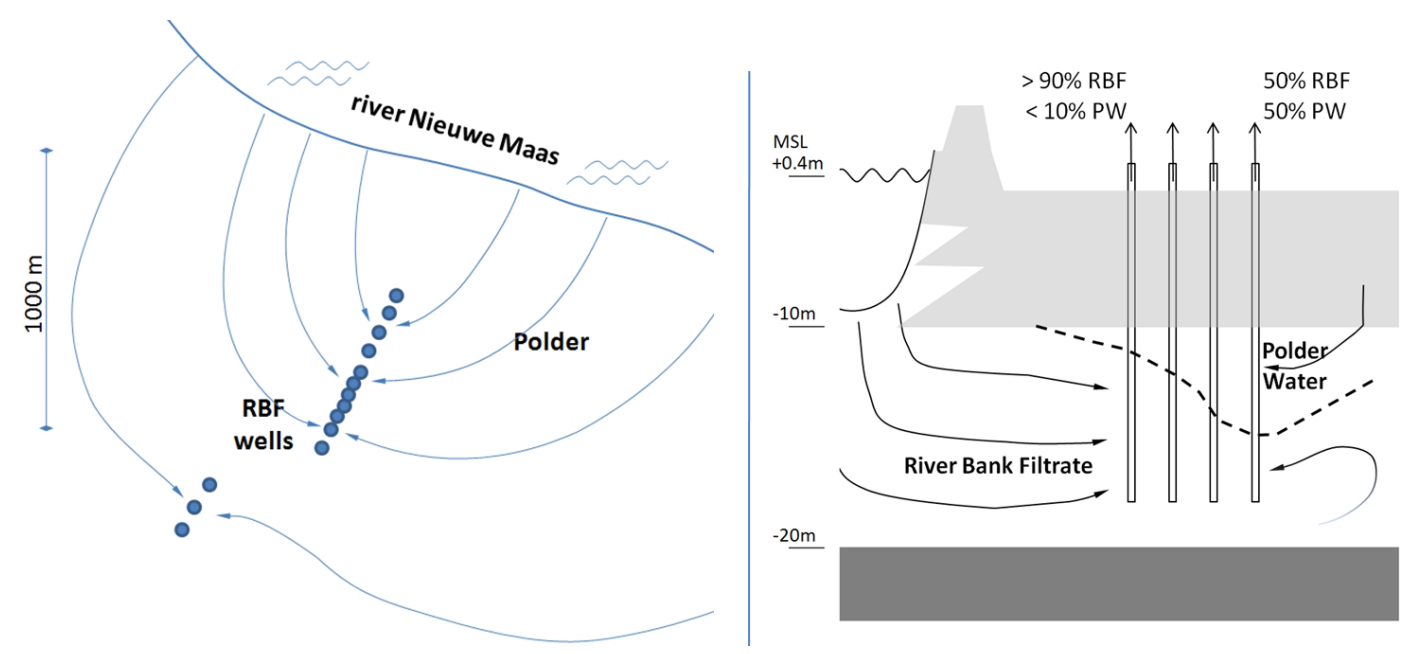

Figure 1. Layout of the Reijerwaard RBF site $\left(51^{\circ} 52^{\prime} \mathrm{N}, 4^{\circ} 35^{\prime} \mathrm{E}\right.$, left) and cross-section of the abstraction of river bank filtrate and PW (right); wells were placed perpendicular to the river to create a larger attenuation (more variation in travel times).

Infiltration implies aquifer passage, resulting in water quality changes. In most cases, the raw groundwater consists of a mix of river bank filtrate and locally infiltrated polder water (PW). This article describes the origin of the concentrations of methane, ammonium, iron, manganese, phosphate and sulfate in the raw water at the Oasen Drinking Water Company in the Netherlands (Oasen). Differences in concentration between individual wells can be explained by the ratio of PW compared to river bank filtrate and by redox processes during transport. Changes in river water composition over the last 50 years also play a role.

Dutch standards for sulfate are so high that removal is not necessary, but results are presented in the hydrology section of this article because it is a good indicator for the changes in redox potential during aquifer passage. The hardness of the water may increase during RBF due to the dissolution of alkaline minerals. Calcium and bicarbonate are not removed by conventional filtration techniques but are reduced efficiently by supplemental techniques such as pellet softening (van Dijk and Wilms, 1991). That, however, will not be discussed in this article.

In the section about treatment, this article focuses on the applied trickling filtration, also known as dry (bio)filtration, as an effective combined treatment step for methane, iron, ammonium and manganese. As part of the joint OasenTUDelft PhD-project "Nitrification in trickling filters for drinking water production", this article further elaborates on possible interactions between the removal processes in a filter. This article focuses further on methane and manganese removal mechanisms and their possible adverse effects on nitrification. Although most analyses presented in this paper were performed according to standard methods in accredited drinking water laboratories, this article is not a research article sensu proprio, lacking the strictly defined structure with
Materials and Methods and Results sections. It presents a general approach to evaluate the functioning of defined parts of the geohydrological and treatment system of Water Treatment Plants. By comparing the extended but still scarcely analyzed datasets from full-scale systems, that are available in many Drinking Water Companies with the appropriate theoretical concepts, interesting deviations and focus points for further research have been formulated.

\section{Bank filtration in Oasen polders, The Netherlands}

\subsection{Oasen groundwater quality}

The Water Treatment Plant (WTP) Reijerwaard uses river bank filtrate as a source for drinking water production. The groundwater is abstracted with vertical wells in a semiconfined aquifer of unconsolidated sandy sediments along the river Nieuwe Maas, which is a branch of the river Rhine. A $10 \mathrm{~m}$ thick Holocene layer of clay and peat sediment lies over the aquifer. The area is a polder below river water level, with a dense network of ditches.

\subsubsection{Hydrology}

The abstracted groundwater consists of a mixture of two anoxic water types with different origins (Fig. 1), compositions and redox states:

- River bank filtrate. Rhine water infiltrating through the river bottom and flowing horizontally through Pleistocene sand deposits to the wells. Subsurface residence times range from 3 to 50 years. This water type accounts for approximately $70 \%$ of the abstracted water.

- PW. Water abstracted from shallow groundwater and ditches through the clay and peat layer. Residence times 


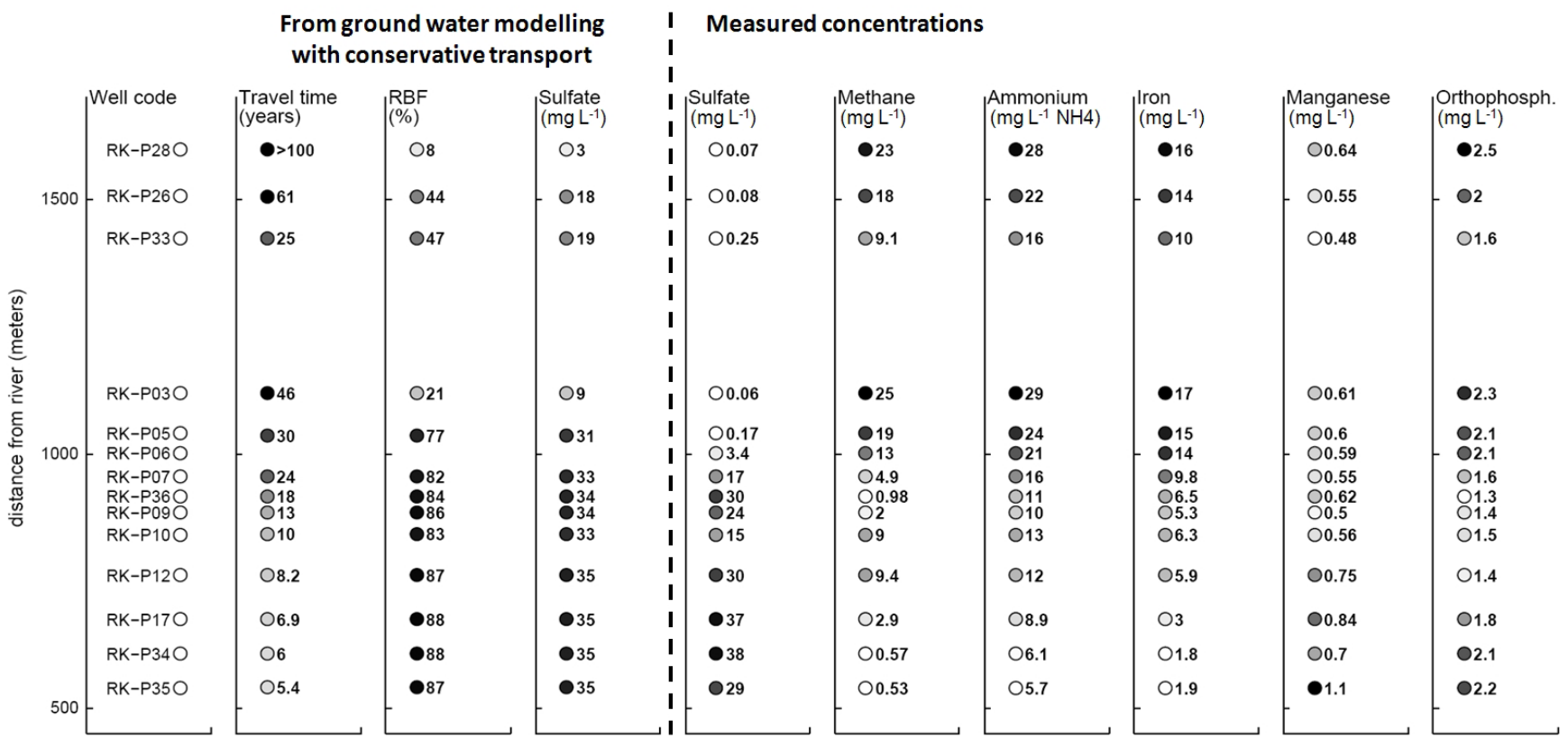

Figure 2. Hydrological characteristics and concentrations in raw water of individual production wells at Oasen WTP Reijerwaard; concentrations are averages for 2005-2009.

range from a year to several decades. The shortest residence time of one year for polder water is a conservative approach. Actually the uncertainty in this travel time is very large. The groundwater model calculates travel times starting from 5 years (in the middle of the well field, with the largest drawdown in piezometric height and a downward flux a little over $2 \mathrm{~mm}$ /day). However, we expect the heterogeneity of the top layer to result in some flow paths with significantly smaller travel times. We have no information on whether this is really one year (or three years or half a year). This water type accounts for approximately $30 \%$ of the total.

As shown in Fig. 1, the hydrologic setting of RBF well fields is such that the wells near the river abstract mainly river bank filtrate, while the share of PW increases with distance from the river. This increase is caused by the longer flow paths for the filtrate - as a function of distance, but even more as a function of time - combined with the increasing drawdown in hydraulic head by the abstraction, causing a larger aquifer recharge with PW. The mixing of river bank filtrate and PW occurs mainly within the wells; in an aquifer, mixing is generally limited.

\subsubsection{Redox processes}

Redox processes are the crucial initiator of changes in composition for both the river bank filtrate and the PW. In general, it can be stated that when organic matter is sufficiently available, it is oxidized by a sequence of redox processes (from Stuyfzand, 1988):
- aerobic respiration

- denitrification

- reduction of manganese and iron

- reduction of sulfate

- methanogenesis

Methanogenesis will generally only occur after all sulfates have been reduced, so methane will only be present simultaneously with sulfate as a result of mixing (Stuyfzand et al., 1994).

For the Reijerwaard well field, Fig. 2 presents hydrological characteristics of the individual production wells from a detailed groundwater model and compares these with measured concentrations in the wells. It shows signs of a lowering redox level with increasing distance and travel time from the river, which is a logical consequence of the increasing share of PW with deep redox conditions.

\subsubsection{Redox parameters sulfate and methane}

In the river water, the annual averages of sulfate concentration have varied between 50 and $80 \mathrm{mg} \mathrm{L}^{-1}$ over the last 30 years. The river bank filtrate reaches the redox level of sulfate reduction while passing the deposits on the river bottom and remnants of the Holocene layers that the river intersects, resulting in sulfate concentrations of one half that of the river water. The PW passes the Holocene clay and peat layer and reaches an even lower redox level, with methanogenesis. Since methane and sulfate do not occur simultaneously, 

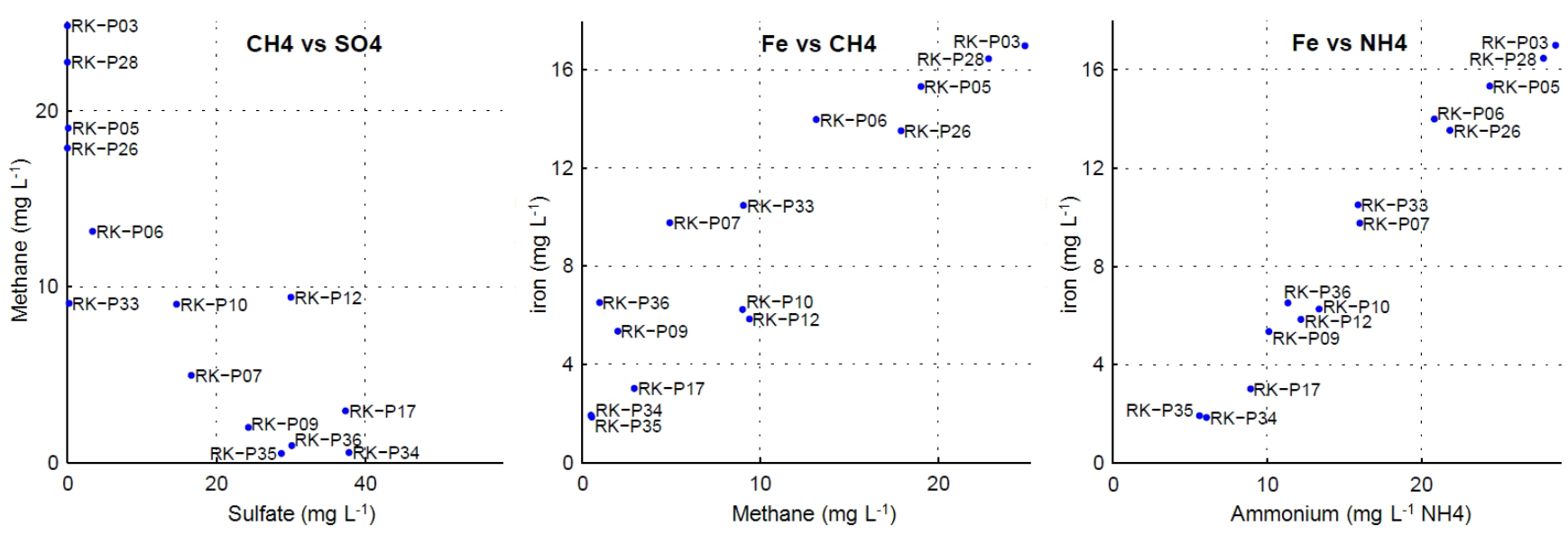

Figure 3. Water qualities of individual wells at the Oasen WTP Reijerwaard; relationship between sulfate and methane; methane and iron; ammonium and iron; averages for 2005-2009.

the methane and sulfate concentrations were used as indicators for estimating the water fractions derived from both origins. PW is identified by the presence of methane and river bank filtrate by the presence of sulfate. Since the ratio of $\mathrm{PW}$ to river bank filtrate determines the methane and sulfate concentrations of individual wells, the concentrations show a negative correlation (Fig. 3). Corresponding to the hydrology, wells near the river abstract mostly river bank filtrate and therefore have low methane and high sulfate concentrations (e.g. wells RK-P12, 17, 34 and 35), while wells at the other side of the well field abstract mostly PW and have high methane and low sulfate concentrations.

Figure 2 compares the measured sulfate concentrations with concentrations based on the calculated mixing ratio of PW and river bank filtrate, where PW contains no sulfate and river bank filtrate contains an assumed concentration of $40 \mathrm{mg} \mathrm{L}^{-1}$ after passing the river deposits. For the wells close to the river the calculated and measured concentrations correspond well, showing the dominant effect of the mixing process of PW and river bank filtrate on the resulting sulfate concentration. With travel times longer than 10 to 20 years, the measured sulfate concentrations, however, are lower than ones the calculated from the share of river bank filtrate. This suggests a process that needs longer travel times to contribute significantly: the reduction of sulfate by the small amounts of organic matter present within the aquifer.

The wells at largest distance from the river will experience another minor influence on sulfate concentrations. These wells partly abstract river bank filtrate over 50 to 70 years of age, originating from a period that Rhine water was less polluted and contained lower sulfate concentrations, contributing to a lower sulfate concentration in the abstracted groundwater.

\subsubsection{Origin of the macro components iron, ammonium, phosphate and manganese}

\section{Origin of iron and ammonium}

For ammonium, an obvious source is the oxidation of nitrogenous (N-containing) organic matter in the confining clay and peat layer, in the river bottom, and to a lesser extent in the aquifer itself. In this process, iron and manganese oxides act as oxidizing agents and dissolve. In river bank filtrate, the iron concentrations are limited because of precipitation as iron sulfides with $\mathrm{HS}^{-}$resulting from subsequent sulfate reduction (Stuyfzand, 1985). This iron sulfide precipitation leaves only very low hydrogen sulfide concentrations in the groundwater. Although mostly below the detection limit, the highest measured concentration of hydrogen sulfides in raw groundwater of another, yet comparable Oasen WTP was $0.03 \mathrm{mg} \mathrm{L}^{-1}$. In the PW, all sulfate has been reduced - even methanogenesis occurs - and iron is introduced from the dissolution of minerals like siderite $\left(\mathrm{FeCO}_{3}\right)$ and vivianite $\left(\mathrm{Fe}_{3}\left(\mathrm{PO}_{4}\right)_{2} \cdot 8\left(\mathrm{H}_{2} \mathrm{O}\right)\right)$ that are common in areas with peat. A further increase in iron concentrations in the aquifer can occur due to the reductive dissolution of iron oxides. The positive relationship between the redox indicator, methane, and iron is illustrated in Fig. 3. This figure also shows a strong positive correlation between iron and ammonium, indicating that a relevant contributing process may be the release of adsorbed or organically bound ammonium during the reductive dissolution of iron oxides.

Compared to river water, ammonium concentrations in river bank filtrate and PW are very high. In the river Rhine, ammonium was present at yearly averaged concentrations over $0.5 \mathrm{mg} \mathrm{L}^{-1} \mathrm{~N}$ before 1990, which has decreased to less than $0.1 \mathrm{mg} \mathrm{L}^{-1} \mathrm{~N}$ in the last decade. In the river water, the ammonium concentration is generally five times higher in winter than in summer; in river bank filtrate, however, no seasonal variation has been observed due to attenuation. 


\section{Origin of manganese}

Manganese concentrations are known to rise to a high level during infiltration from the river. At WTP Reijerwaard, and in the nearby Opperduit test location, studied by Stuyfzand and Lüers (1996), concentrations are found of 1.4 and $1.5 \mathrm{mg} \mathrm{L}^{-1}$, in observation wells at several tens of meters after infiltration into the aquifer. Stuyfzand (1985) assumed that manganese mainly originates from the reductive dissolution of manganese oxides and observed that the river bank filtrate is in equilibrium with $\mathrm{MnCO}_{3}$ precipitate which may be a source, but also a limit, for the manganese concentration.

The high concentration of manganese in the river bank filtrate decreases with travelling time and distance after infiltration. This decrease is visible in the raw water concentrations of the first five wells shown in Fig. 2 and is also found in a row of observation wells perpendicular to the river at Opperduit (Stuyfzand and Lüers, 1996). At the far half of the well field, away from the river, the manganese concentration in the river bank filtrate has decreased to a low level, and PW contributes predominantly to the concentrations that are found in the wells. Here, the highest concentrations are found in the wells with the highest share of PW.

\section{Origin of orthophosphate}

Orthophosphate originates from the dissimilation of organic matter and the dissolution of phosphate minerals, with vivianite as the most important one. From Fig. 2 it can be concluded that both the river bank filtrate and PW contain high concentrations. In the river bank filtrate, however, a decrease in the orthophosphate concentration is observed with increasing distance from the river, probably as a consequence of adsorption on iron (oxy)hydroxides present in the aquifer.

\subsubsection{Geochemistry of aquifer sediments}

The availability of iron and manganese oxides is, of course, a condition for their reductive dissolution. Samples of the aquifer sediment on a nearby well field (WTP Lekkerkerk) confirm their presence in large quantities. Analysis showed 1000 to $3000 \mathrm{mg} \mathrm{kg}^{-1}$ by dry weight of amorphous iron (oxy)hydroxides in the sediment (extractable with oxalic acid), whereas a similar amount was found in the form of ferrous iron precipitates as iron sulfides, like pyrite, and in the form of crystalline iron oxides (extractable with aqua regia). For manganese, the samples showed concentrations of 30 to $60 \mathrm{mg} \mathrm{kg}^{-1}$ of dry weight of easily soluble manganese oxides, manganese carbonate (rhodochrosite) and reduced species mainly adsorbed to iron (oxy)hydroxides. A similar amount of manganese was found in more persistent manganese containing minerals. These iron and manganese precipitates might be source or sink for dissolved iron and manganese species.

\subsection{Oasen groundwater treatment}

The complex mixture of river bank filtrate and PW in the groundwater poses a number of challenges in the treatment process. Before discussing some of these issues based on long-term observations in existing, full-scale filters systems, the next paragraph provides an overview of existing treatment processes for the removal of the relevant macro components.

\subsubsection{Removal processes for macro components}

The presence of the macro components methane, iron, ammonium and manganese is unwanted in the drinking water for several reasons and, therefore, is severely restricted by drinking water standards. The compounds can be removed from the groundwater by a wide array of physical, chemical and microbiological processes, or combinations of them. All four compounds can be removed by oxidation with oxygen or a chemical oxidizing agent like ozone, permanganate or peroxide. In all cases, the oxidation can be biologically catalyzed, or indeed sometimes is strictly biologi$\mathrm{cal}$, like for methane, ammonium and manganese under neutral conditions with oxygen as the only oxidizing agent. In the bacterial processes, the (catabolic) oxidation reaction is used for energy generation and growth of the bacteria. Nonoxidative removal processes range from membrane filtration through flocculation, sedimentation and filtration to adsorption or gas stripping. The membrane filtration techniques of reverse osmosis and nanofiltration, although rather effective for removal of iron and manganese, are generally not applied for the removal of only inorganic macro components. An overview of applicable removal processes is given in Table 1.

\subsubsection{Oasen groundwater treatment systems}

In groundwater treatment in the Netherlands, only oxygen from the air and no chemical agents are used for oxidation purposes. The central process for treatment of river bank filtrate/PW groundwater is filtration over a granular medium, in most cases single layer silica sand, but other bed configurations (dual layer) and materials (e.g. anthracite, expanded clay pellets) are increasingly used. Because of the oxygen demand of the macro component removal processes, the anoxic groundwater requires aeration before or during filtration. In some cases a simple spraying directly on top of the filter bed may suffice, but in most cases there is a specialized gas exchange process step before filtration. Such a gas exchange step will also strip oversaturated gases like methane and carbon dioxide from the groundwater. Removal of the latter increases the $\mathrm{pH}$ of the water, which in turn may stimulate the oxidation of iron, ammonium and manganese, the rates of which are proportionate to $\mathrm{OH}^{-}$concentrations squared in circumneutral circumstances. The scheme of typical Dutch groundwater treatment is shown in Fig. 4. 
Table 1. Removal processes for groundwater macro components.

\begin{tabular}{|c|c|c|c|c|}
\hline \multirow[b]{2}{*}{ Component } & \multirow[b]{2}{*}{$\begin{array}{l}\text { Reduction-oxidation } \\
\text { reaction (with } \mathrm{O}_{2} \text { ) }\end{array}$} & \multirow{2}{*}{$\begin{array}{l}\text { Microbial } \\
\text { Microorganisms } \\
\text { (Madigan and } \\
\text { Martinko, 2005) }\end{array}$} & \multicolumn{2}{|c|}{ Physical-chemical } \\
\hline & & & Oxidation context & $\begin{array}{l}\text { Alternative processes } \\
\text { (de Moel et al. (Eds.), } \\
\text { 2006) }\end{array}$ \\
\hline Methane & $\begin{array}{l}\mathrm{CH}_{4}+2 \mathrm{O}_{2} \\
\rightarrow \mathrm{CO}_{2}+2 \mathrm{H}_{2} \mathrm{O}\end{array}$ & $\begin{array}{l}\text { Methylotrophs like } \\
\text { Methylophilus spp., } \\
\text { Methylomonas spp., } \\
\text { Methylobacter spp., } \\
\text { (de Vet et al., 2009a) }\end{array}$ & - & Stripping \\
\hline Iron & $\begin{array}{l}\mathrm{Fe}^{2+}+\frac{1}{4} \mathrm{O}_{2}+1 \frac{1}{2} \mathrm{H}_{2} \mathrm{O} \\
\rightarrow \mathrm{FeOOH}+2 \mathrm{H}^{+}\end{array}$ & $\begin{array}{l}\text { Gallionella ferruginea, } \\
\text { Leptothrix ochracea., } \\
\text { Sphaerotilus natans, } \\
\text { Toxothrix Trichogenes } \\
\text { (Czekalla et al., 1985; } \\
\text { Emerson and Moyer, } \\
\text { 1997) }\end{array}$ & $\begin{array}{l}\text { Adsorptive oxidation } \\
\text { (Sharma et al., 2001) } \\
\text { Homogenous oxidation }\end{array}$ & $\begin{array}{l}\text { (Reverse osmosis, } \\
\text { nanofiltration) } \\
\text { Flocculation, settling, } \\
\text { floc or flocking } \\
\text { filtration }\end{array}$ \\
\hline Ammonium & $\begin{array}{l}2 \mathrm{NH}_{4}^{+}+3 \mathrm{O}_{2} \rightarrow \\
2 \mathrm{NO}_{2}^{-}+4 \mathrm{H}^{+}+2 \mathrm{H}_{2} \mathrm{O} \\
2 \mathrm{NO}_{2}^{-}+\mathrm{O}_{2} \rightarrow 2 \mathrm{NO}_{3}^{-}\end{array}$ & $\begin{array}{l}\text { Nitrosomonas spp., } \\
\text { (Nitrosospira spp., } \\
\text { Nitrosolubus spp.), } \\
\text { Ammonia-oxidizing } \\
\text { Archaea } \\
\text { Nitrospira spp., } \\
\text { (Nitrobacter } \text { spp.) } \\
\text { (de Vet et al., 2009a) }\end{array}$ & $\begin{array}{l}\text { (Breakpoint } \\
\text { chlorination) } \\
\text { (not applied in } \\
\text { the Netherlands) }\end{array}$ & $\begin{array}{l}\text { Stripping of ammonia } \\
\text { (high } \mathrm{pH} \text { ), } \\
\text { Adsorption on zeolites } \\
\text { (reverse osmosis) }\end{array}$ \\
\hline Manganese & $\begin{array}{l}2 \mathrm{Mn}^{2+}+\frac{1}{2} \mathrm{O}_{2}+2 \mathrm{H}_{2} \mathrm{O} \\
\rightarrow \mathrm{Mn}_{2} \mathrm{O}_{3}+4 \mathrm{H}^{+}\end{array}$ & $\begin{array}{l}\text { Manganese-oxidizing } \\
\text { bacteria like } \\
\text { Leptothrix spp., } \\
\text { Metallogenium spp., } \\
\text { Hyphomicrobium spp., } \\
\text { Siderocapsa spp., } \\
\text { Siderocystis spp. } \\
\text { (Czekalla et al., 1985) }\end{array}$ & $\begin{array}{l}\text { Autocatalytic oxidation } \\
\text { Homogeneous } \\
\text { oxidation with strong } \\
\text { oxidants like } \\
\text { permanganate }\end{array}$ & $\begin{array}{l}\text { (Reverse osmosis, } \\
\text { nanofiltration) } \\
\text { Flocculation, settling, } \\
\text { floc or flocking } \\
\text { filtration }\end{array}$ \\
\hline
\end{tabular}

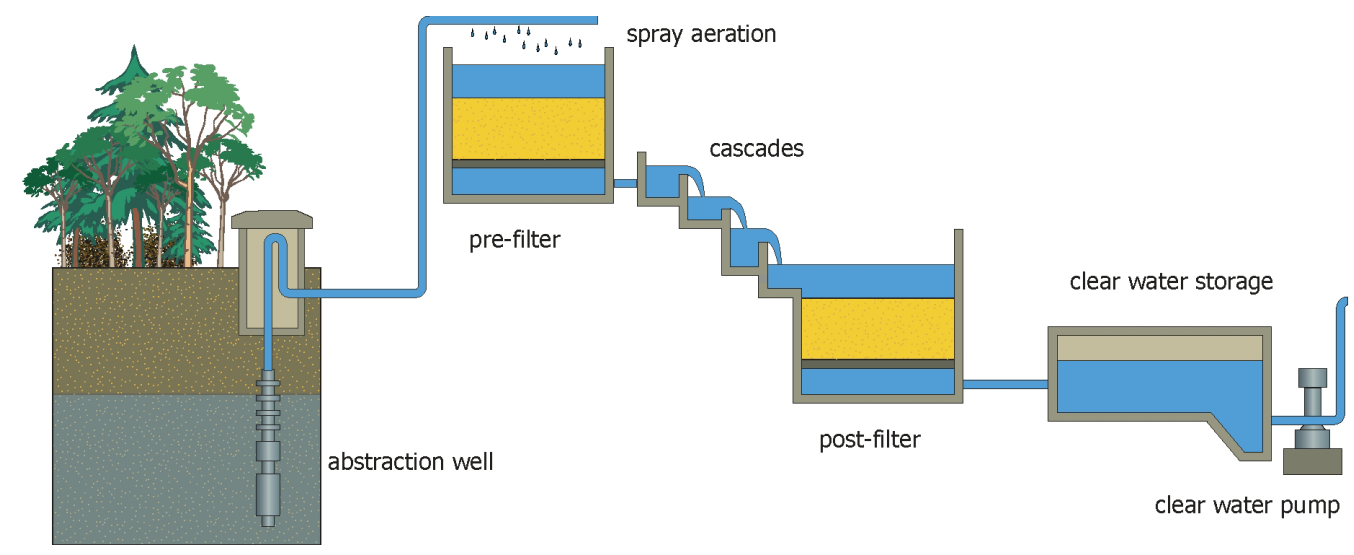

Figure 4. Artist impression of a conventional groundwater treatment system in the Netherlands with submerged sand filters. 
Due to the high oxygen consumption of ammonia oxidation (4.6 $\mathrm{mg} \mathrm{O}_{2}$ per $\mathrm{mg} \mathrm{NH}_{4}-\mathrm{N}$, as follows from the stoichiometry in Table 1), trickling filtration (also called dry biofiltration) is applied in cases of high ammonium content in the groundwater, like at several Oasen WTPs. As an alternative, submerged (also called wet) filtration with the injection of pure oxygen might be considered in these situations.

Of the four groundwater components considered, only ammonium and manganese removal pose regular problems for Oasen. The nitrification problems have previously been described by de Vet et al. (2009b). Iron removal in itself is never problematic for Oasen but some of its possible interactions with nitrification were discussed in that earlier paper. It also contained a number of the many relevant references about the interaction of iron, manganese and ammonium in groundwater filters (Mouchet, 1992; Vandenabeele et al., 1995; Śtembal et al., 2005; Tekerlekopoulou et al., 2006). The role of microbial iron oxidation, although possibly of importance in the Oasen trickling filters, will not be discussed here. For methane and manganese, different removal mechanisms and their interactions with nitrification are discussed in the next two sections.

\subsubsection{Methane removal and its effect on nitrification}

Methane removal can be achieved physically by stripping, or biologically by methane-oxidizing bacteria. Biological degradation is characterized by a relatively high biomass over substrate yield (19 to $70 \%$ of the substrate carbon is incorporated into cell material; Leak and Dalton, 1986), and may lead to the clogging of filter material by production of extracellular polymeric substances (Streese and Stegmann, 2003). Therefore, because biological methane oxidation may interfere with other filtration processes, it is generally not chosen.

Several systems for intensive gas transfer, such as cascades, tower and plate aerators and high pressure spraying, are effectively applied in full-scale plants for this purpose. A vacuum stripper is applied in situations were aeration is unwanted, as is the case in front of trickling filtration, to avoid clogging the distribution spraying with oxidation products. The stripping efficiency for dissolved gases is determined by gas properties, especially the water/air distribution (or Henry) coefficient, and system characteristics for the equilibrium state (determined by the air-to-water ratio, $R Q$ ), and kinetics (described by the transfer coefficient). The distribution coefficients in Table 2 show methane's lower affinity for water compared to that of carbon dioxide, implying a better removal of the former under the same system characteristics. Oxygen and methane are comparable in this respect. The constant temperature of the Oasen groundwater means fixed equilibria for the gas distribution, unlike for surface water and river bank filtrate with short travel times, where a rise in water temperature results in lower water solubility of the gases and an increased driving force for stripping.
Table 2. Molecular Weight (MW; $\mathrm{g} \mathrm{mol}^{-1}$ ) and distribution coefficients (mass in water/mass in air) for methane, oxygen and carbon dioxide (de Moel et al. (Eds.), 2006).

\begin{tabular}{lccccc}
\hline & & $\mathrm{MW}$ & $0{ }^{\circ} \mathrm{C}$ & $10{ }^{\circ} \mathrm{C}$ & $20^{\circ} \mathrm{C}$ \\
\hline Methane & $\mathrm{CH}_{4}$ & 16.0 & 0.0556 & 0.0433 & 0.0335 \\
Oxygen & $\mathrm{O}_{2}$ & 32.0 & 0.0493 & 0.0398 & 0.0337 \\
Carbon dioxide & $\mathrm{CO}_{2}$ & 44.0 & 1.71 & 1.23 & 0.942 \\
\hline
\end{tabular}

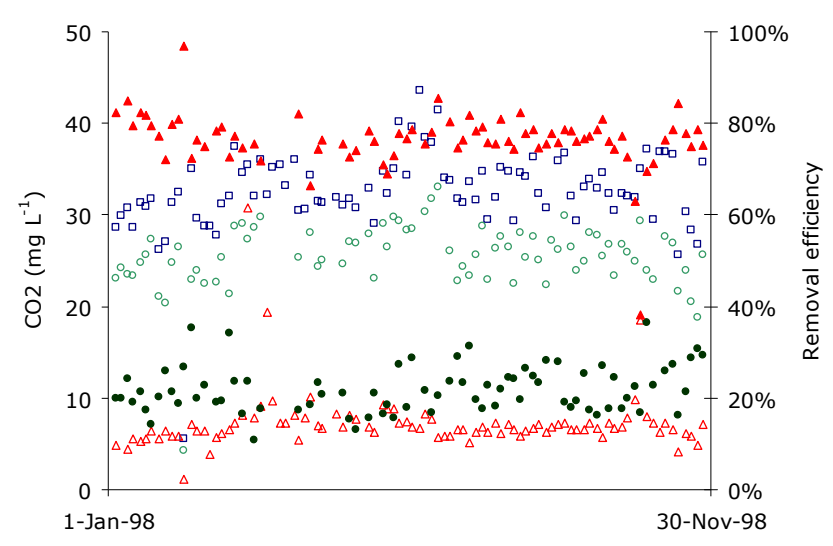

Figure 5. Carbon dioxide concentrations and removal efficiencies for vacuum stripper and trickling filtration at Oasen WTP Lekkerkerk, period January-November 1998; open symbols, concentrations: $\square$ raw water; $\circ$ effluent vacuum stripper; $\Delta$ effluent trickling filter; solid symbols, removal efficiencies: • vacuum stripper; $\Delta$ trickling filter.

The difference in removal efficiencies for methane and carbon dioxide is illustrated in Table 3 for the full-scale gas transfer systems at two Oasen WTPs. The vacuum stripper had distinctly lower gas removal efficiency for carbon dioxide than the cascade did. For methane, the difference was less pronounced, and both systems achieved over $90 \%$ efficiency.

Methane will be completely removed by trickling filtration. Although methane is not measured above the detection limit in the trickling filter effluent, no direct assessment can be made of the role of physical and biological methane removal. However, from the removal efficiency for carbon dioxide, it can be concluded that the air stripping of the trickling filters performed much better than the vacuum stripper at Oasen WTP Lekkerkerk (Fig. 5). The trickling filter contained coarse filter sand (1.7-2.5 mm), was concurrently ventilated with an $R Q$ of 10 and had an average filtration rate of $2.2 \mathrm{~m} \mathrm{~h}^{-1}$.

The removal efficiency for carbon dioxide was over $75 \%$ for the trickling filter, which is comparable to the removal efficiency of cascade aeration (see Table 3). Before the startup of the acidifying nitrification and manganese removal, the carbon dioxide stripping efficiency in the trickling filter was 
Table 3. Methane and carbon dioxide in- and outgoing concentrations and stripping efficiency for two Oasen full-scale gas exchange systems.

\begin{tabular}{llllll}
\hline & & \multicolumn{2}{c}{$\begin{array}{c}\text { WTP Reijerwaard } \\
\text { Cascades * }\end{array}$} & \multicolumn{2}{c}{$\begin{array}{c}\text { WTP Lekkerkerk } \\
\text { Vacuum stripper ** }\end{array}$} \\
\hline & Driving force AVG (MIN) & \multicolumn{2}{c}{$R Q=24(5.4)$} & \multicolumn{2}{c}{$\mathrm{P}=6 \mathrm{kPa}$} \\
& Hydraulic load AVG (MAX) & \multicolumn{2}{c}{$\begin{array}{l}\text { 37 (165) } \mathrm{m}^{3} \mathrm{~h}^{-1} \mathrm{~m}^{-1} \\
\end{array}$} & \multicolumn{2}{c}{$50(90) \mathrm{m}^{3} \mathrm{~h}^{-1} \mathrm{~m}^{-2}$} \\
\hline & & $\mathrm{CH}_{4}$ & $\mathrm{CO}_{2}$ & $\mathrm{CH}_{4}$ & $\mathrm{CO}_{2}$ \\
$\mathrm{IN}$ & $\left(\mathrm{mg} \mathrm{L}^{-1}\right)$ & $7.2 \pm 1.7$ & $103 \pm 36$ & $0.93 \pm 0.31$ & $32.6 \pm 4.4$ \\
OUT & $\left(\mathrm{mg} \mathrm{L}^{-1}\right)$ & $0.28 \pm 0.08$ & $23.7 \pm 3.4$ & $0.08 \pm 0.03$ & $25.5 \pm 3.6$ \\
Efficiency & $\%$ & $95.7 \pm 1.7$ & $72.3 \pm 9.0$ & $90.8 \pm 2.6$ & $21.9 \pm 5.0$ \\
\hline
\end{tabular}

Efficiency $=\left(C_{\text {in }}-C_{\text {out }}\right) / C_{\text {in }} ; R Q=$ air to water ratio $v / v$

* values for 1995-2004

** values for Jan-Nov 1998

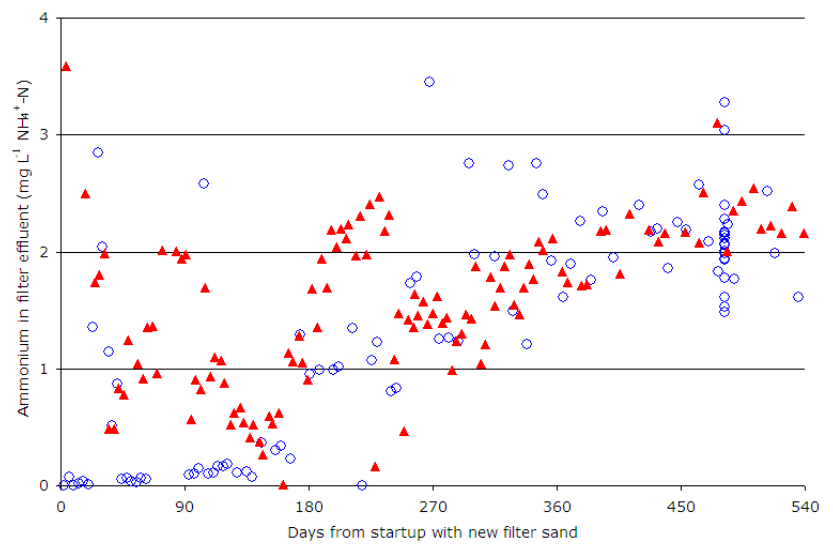

Figure 6. Ammonium concentrations in the effluents of trickling filters at Oasen WTP Lekkerkerk; $\Delta$ PLTOFF08 with pretreatment by vacuum stripping (October 1998 to April 2000), o PLTOFF05 without pretreatment by vacuum stripping (March 1999 to September 2000); the low concentrations during the first months in the effluent of PLTOFF05 were mainly caused by a reduced raw water flow.

even higher than $90 \%$. The supposed predominance of physical over biological methane removal was confirmed by two more direct methods. First, when balancing the fluxes of methane entering (by water) and leaving (by water and air) the filter, the average and standard deviation for the physical removal efficiency in six trickling filters at several Oasen WTPs was $84 \% \pm 12 \%$. Differences before and after backwash were found to be within the boundaries of uncertainty. Secondly, the methane-oxidizing activity measured in batch experiments varied only slightly between sand samples taken from trickling filters at Oasen WTP Lekkerkerk with and without pretreatment by vacuum stripping.

Figure 6 shows that pretreatment of the groundwater by vacuum stripping had no clear effect on the nitrification in the trickling filters.

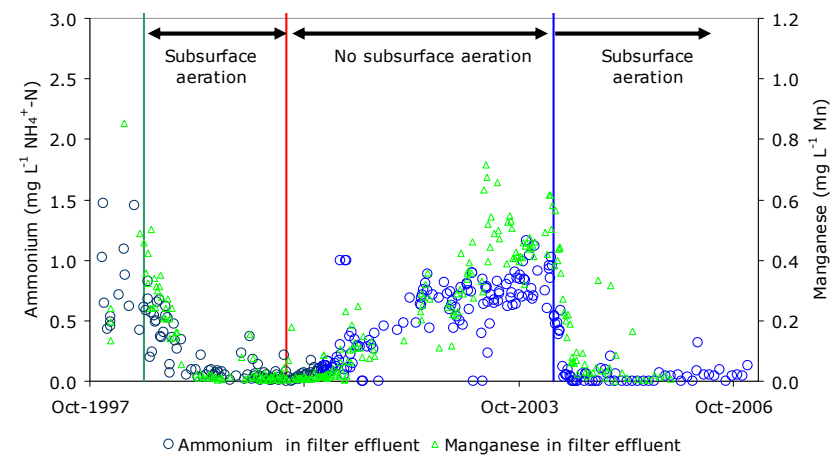

Figure 7. Ammonium (o) and manganese $(\triangle)$ concentrations in the trickling filter effluent in periods with and without subsurface aeration in the Oasen WTP Lekkerkerk's Schuwacht well field.

\subsubsection{Manganese removal and its effect on nitrification}

Without strong oxidizing chemicals, manganese oxidation under circumneutral circumstances may occur chemically (Graveland and Heertjes, 1975) and biologically (Czekalla et al., 1985).

A comparison of full-scale trickling filters at Oasen WTP Lekkerkerk shows some interesting differences in manganese removal and its occurrence in combination with nitrification problems. At this WTP, groundwater from two separated well fields (Schuwacht and Tiendweg) is also treated with separated double trickling filters. In the Schuwacht well field, subsurface aeration (Appelo et al., 1999) - a very mild form of in situ iron removal - is applied for the enhancement of nitrification. Figure 7 shows that the enhancement of subsurface aeration worked for manganese removal as it did for nitrification and the interruption of the technique resulted in a similar relapse for both processes.

Incomplete nitrification, however, does not always coincide with incomplete manganese removal. Figure 8 shows that, despite incomplete nitrification, manganese removal was not severely reduced in another full-scale trickling filter, 


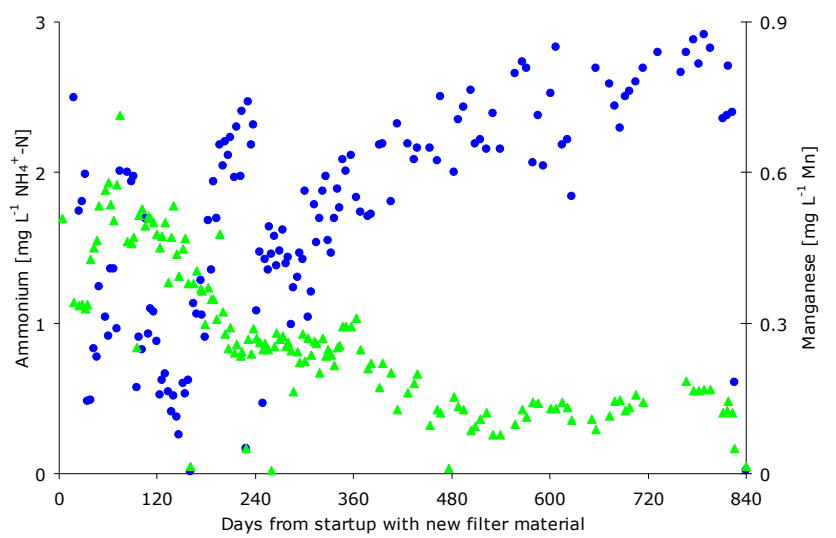

Figure 8. Ammonium $(\bullet)$ and manganese $(\boldsymbol{\Delta})$ concentrations in the trickling filter effluent treating normal groundwater from the Oasen WTP Lekkerkerk's Tiendweg well field.

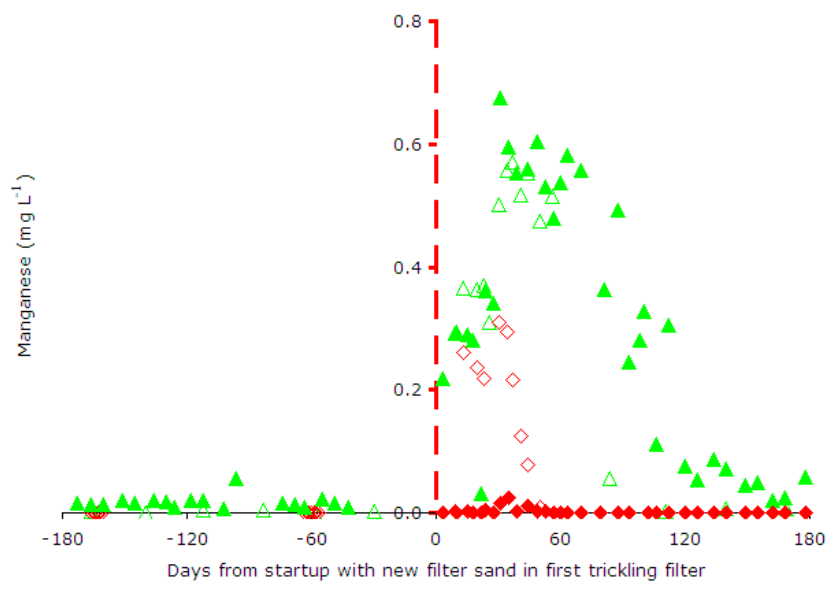

Figure 9. Manganese concentrations in the effluent of the first and second filter of double trickling filter sets at the Oasen WTP Lekkerkerk around the startup with fresh filter sand in the first trickling filter; $\Delta$ and $\diamond$ effluent of first and second subsurface aerated filter, $\boldsymbol{\Delta}$ and $\bullet$ effluent of first and second non-subsurface aerated filter.

which treated normal, non-subsurface aerated groundwater from the Tiendweg well field.

Remarkable differences were also observed in the second trickling filter of the double filter sets during startup with fresh filter sand only in the first trickling filter (Fig. 9). Each first filter was directly coupled to its own second filter, making the effluent of the former the influent of the latter. From the startup with new filter material in the first filter, the manganese removal was almost complete in the second filter of the non-subsurface aerated double filter set. In the subsurface aerated double filter set, both the first and second filter required a startup period of over a month for manganese removal.
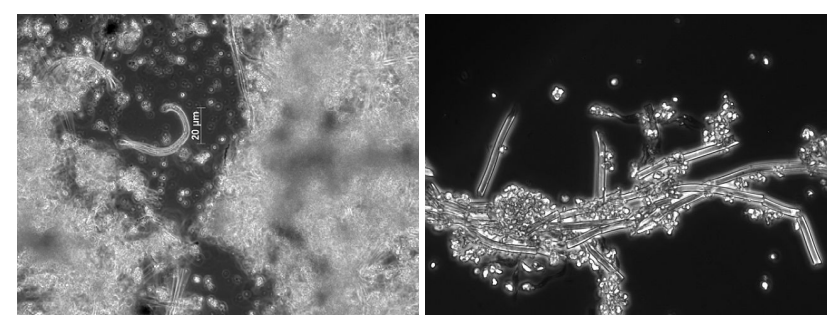

Figure 10. Phase-contrast pictures of backwash water from first trickling filters at Oasen WTP Lekkerkerk; mainly inorganic flocs in backwash water from a subsurface aerated filter (left, 630X), mainly biological deposits from a non-subsurface aerated filter (right, 1000X).

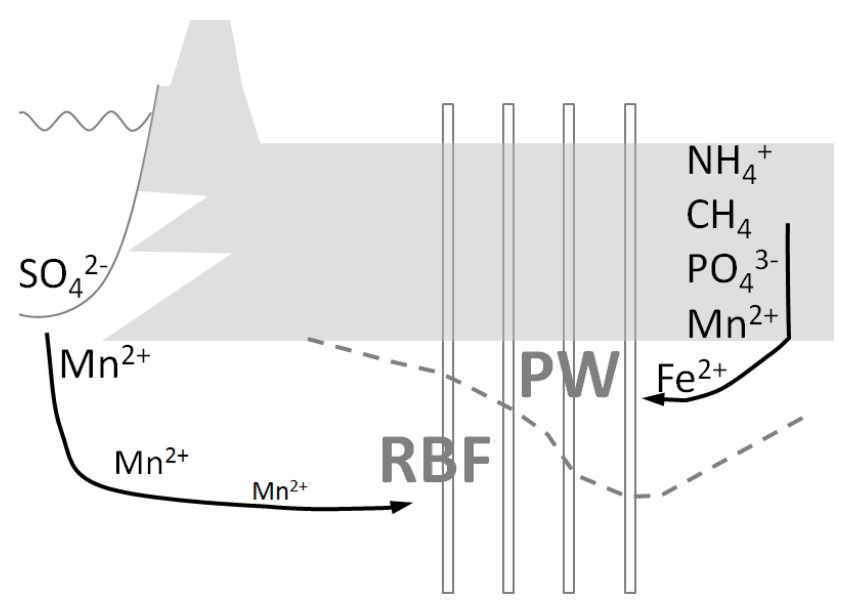

Figure 11. Schematic presentation of the origin of discussed parameters.

The backwash water from a non-subsurface aerated first trickling filter contained more biological formed iron(oxi)hydroxide deposits, resembling those of the Leptothrix ochracea (Czekalla et al., 1985), iron- and possibly manganese-oxidizing bacteria (Fig. 10).

\section{Discussion}

\subsection{Origin of macro components}

When abstracting river bank filtrate, it is nearly inevitable that PW is also attracted and abstracted. The abstraction, therefore, results in a raw water mix of both water types, of which the origins are illustrated in Fig. 11, together with their macro component contributions of interest. The figure shows that PW accounts for the methane and high loads of iron and ammonium, which are relevant for the filtration steps. River bank filtrate and PW contribute an approximately equal load of manganese to the total raw water. 


\subsection{Influencing the ratio of PW to river bank filtrate}

River bank filtrate offers a better source for producing drinking water than PW, considering ammonium and iron concentrations. So, with the operation and the design of well fields, it is favorable to maximize the share of river bank filtrate. The percentage of river bank filtrate can be influenced by changing the location of a well field relative to the river or by choosing a location with favorable hydrological conditions. For example, a location close to the river in a polder far below river level will result in a relatively high share (\%) of river bank filtrate. But moving well fields is generally not realistic, and other factors, such as spatial-planning-conflicts and adverse effects of a new abstraction (especially land subsidence), will be more important than these aspects of water quality.

For existing well fields, it is a technically challenging idea to separately abstract (and treat) PW and river bank filtrate. Considering the distribution of the PW and river bank filtrate both in the horizontal plane and in depth, as shown in Fig. 11, a technical solution would be to equip each well with two separate screens and pumps. Well screen depth and pump capacity are designed so that the deep screen abstracts only river bank filtrate, while the shallower screen abstracts only PW. As both screens are in the same aquifer, separate abstraction should be achieved by finding the right balance in abstraction rate between the shallow and the deep screen.

\subsection{Pretreatment or direct trickling filtration for methane stripping}

Full-scale trickling filters at Oasen are versatile removal systems, in optimal conditions capable of removing over $1 \mathrm{~g}$ of methane, $10 \mathrm{~g}$ of iron, $8 \mathrm{~g}$ of ammonium and $1 \mathrm{~g}$ of manganese per hour and $\mathrm{m}^{3}$ of filter bed almost completely. Physical, chemical and biological processes occur simultaneously. Methane is predominantly removed by stripping and the remaining microbial methane-oxidizing activity in Oasen trickling filters was, at most, about $0.7 \mathrm{~g}$ methane per hour and $\mathrm{m}^{3}$ of filter bed only in the upper layer of the filter bed. This is moderate compared to the maximum methaneoxidizing activity measured at a landfill gas treatment filter (63 $\mathrm{g}$ methane per hour and $\mathrm{m}^{3}$ of filter bed; Streese and Stegmann, 2003). In the Oasen trickling filters, ammoniaoxidizing microorganisms may even account for part of the methane-oxidation. Pretreatment by vacuum stripping for methane removal had no effect on the nitrification in the trickling filters. Thus, in well-ventilated trickling filters, biological methane oxidation is limited and does not compete with nitrification. Proper assessment of the physical methane removal capabilities of the trickling filter is recommended to prevent building a costly, but ineffective, extra pretreatment step preceding trickling filtration.

\subsection{Manganese removal mechanism and problems}

Like in iron oxidation (Sharma et al., 2005), the role of microorganisms in manganese oxidation is being debated. Although no conclusions about the steady state can be drawn, manganese-oxidizing bacteria have been shown to play an important role in the startup of the process (Burger et al., 2008). Observations of the full-scale filters at Oasen WTP Lekkerkerk suggest that the role of bacteria in manganese oxidation may be distinctly different under deviating conditions. Thermodynamically, ammonia and nitrite oxidation precede manganese oxidation and the inhibitory effects of incomplete nitrification on manganese removal have been reported by Vandenabeele et al. (1995). With this in mind, we anticipated the results of the subsurface aerated first trickling filter, where incomplete manganese removal accompanied the nitrification problems. The combination of severely inhibited nitrification without similar manganese removal problems in the non-subsurface aerated filter can not be explained is this manner.

The immediate and almost complete manganese removal in the second filter of the non-subsurface aerated filter set after startup in the first filter is remarkable as well. According to Graveland and Heertjes (1975), the autocatalysis of manganese only occurs with unstable manganese oxides like $\mathrm{Mn}_{3} \mathrm{O}_{4}$. These transform over time into more oxidized and stable phases like $\mathrm{MnO}_{2}$, losing their catalytic capacity, requiring a constant regeneration of the deposition by freshly formed manganese oxides. Therefore, it should be expected that filter material in the second filters does not contain the unstable, catalyzing manganese coating after more than half a year without a supply of manganese in the filter influent. Finally, the microscopic pictures from the backwash water show microbially formed deposits by iron- or manganese-oxidizing bacteria. From this we hypothesize that manganese (and iron) oxidation is predominantly bacteriological in Oasen trickling filters treating normal groundwater. We further hypothesize that subsurface aeration enhances the chemical removal of manganese (and iron), thus limiting the growth of these bacteria. Finally, we hypothesize that the growth of competing iron- and manganese-oxidizing bacteria in trickling filters leads to the inhibiting of nitrifying microorganisms.

\section{Future research questions}

- What processes control manganese concentrations in groundwater, and can they be influenced underground?

- How can PW and river bank filtrate be abstracted separately? Is separate abstraction of river bank filtrate and PW feasible? And how much mixing is inevitable?

- What are optimal/fitting treatment schemes for both separated water types? 
- Under what conditions does microbial iron and manganese oxidation occur?

- Does increased growth of iron- and manganeseoxidizing bacteria result in nutrient limitation for ammonia-oxidizing bacteria?

- Does subsurface aeration inhibit growth of iron- and manganese-oxidizing bacteria?

\section{Conclusions}

- The raw water at the OASEN Drinking Water Company consists of a mixture of two water types, polder water and river bank filtrate, which have distinct differences in composition, related to their redox levels;

- Polder water has the lowest redox level and accounts for the larger part of the macro components methane, ammonium and iron, while river bank filtrate contributes most to the manganese content of raw water;

- Trickling filtration can be a highly efficient and versatile removal system for macro components in polder river bank filtrate including stripping of methane;

- Manganese oxidation is probably predominantly microbial in trickling filtration of polder river bank filtrate;

- Coincidence of incomplete manganese removal and nitrification may indicate competition for phosphate or essential trace substrates in biological processes.

Acknowledgements. We would like to acknowledge Wilfred Burger (formerly Oasen, currently Logisticon Water Treatment), Jan-Dik Verdel (Royal Haskoning), Dirk van der Woerdt (formerly Oasen, currently Groningen Water Company), and Anke Wolthoorn (formerly Wageningen University, currently Paques BV) for their contributions to the research on methane removal.

Edited by: B. Heijman

\section{References}

Appelo, C. A. J., Drijver, B., Hekkenberg, R., and Jonge, M.: Modeling In Situ Iron Removal from Ground Water, Ground Water, 37(6), 811-817, 1999.

Burger, M. S., Krentz, C. A., Mercer, S. S., and Gagnon, G. A.: Manganese removal and occurrence of manganese oxidizing bacteria in full-scale biofilters, J. Water Supply Res. T., 57(5), 351$359,2008$.
Czekalla, C., Mevius, W., and Hanert, H.: Quantitative removal of iron and manganese by microorganisms in rapid sand filters (in situ investigations), Water Supply, 3(1), 111-123, 1985.

de Moel, P. J., Verberk, J. Q. J. C., and van Dijk, J. C. (Eds.): Drinking water: principles and practice, Singapore, World Scientific, 2006.

de Vet, W. W. J. M., Dinkla, I. J. T., Muyzer, G., Rietveld, L. C., and van Loosdrecht, M. C. M.: Molecular characterization of microbial populations in groundwater sources and sand filters for drinking water production, Water Res., 43(1), 182-194, 2009a.

de Vet, W. W. J. M. Rietveld, L. C., and van Loosdrecht, M. C. M.: Influence of iron on nitrification in full-scale drinking water trickling filters, J. Water Supply Res. T., 58(4), 247-256, doi:10.2166/aqua.2009.115, 2009b.

Emerson, D. and Moyer, C.: Isolation and characterization of novel iron-oxidizing bacteria that grow at circumneutral pH, Appl. Environ. Microb., 63(12), 4784-4792, 1997.

Graveland, A. and Heertjes, P. M.: Removal of manganese from ground water by heterogeneous autocatalytic oxidation, Trans. Inst. Chem. Eng., 53, 154-164, 1975.

Leak, D. J. and Dalton, H.: Growth yields of methanotrophs. I. Effect of copper on the energetics of methane oxidation, Appl. Microbiol. Biot., 23(6), 470-476, 1986.

Madigan, M. T. and Martinko, J. M.: Brock Biology of Microorganisms, Upper Saddle River (New Jersey), Prentice-Hall, Edn. $11,2005$.

Mouchet, P.: From conventional to biological removal of iron and manganese in France, J. Am. Water Works Ass., 84(4), 158-167, 1992.

Sharma, S. K., Kappelhof, J., Groenendijk, M., and Schippers, J. C.: Comparison of physicochemical iron removal mechanisms in filters, J. Water Supply Res. T., 50(4), 187-198, 2001.

Sharma, S. K., Petrusevski, B., and Schippers, J. C.: Biological iron removal from groundwater: A review, J. Water Supply Res. T., 54(4), 239-247, 2005.

Sontheimer, H.: Trinkwasser aus dem Rhein? Bericht über ein vom Bundesminister für Forschung und Technologie gefördertes Verbundforschungsvorhaben zur Sicherheit der Trinkwassergewinnung aus Rheinuferfiltrat bei Stossbelastungen, Academia Verlag, Sankt Augustin, Germany, 1991.

Štembal, T., Markic, M., Ribiĉić, N., Briški, F., and Sipos, L.: Removal of ammonia, iron and manganese from groundwaters of northern Croatia - Pilot plant studies, Process Biochem., 40(1), 327-335, 2005.

Streese, J. and Stegmann, R.: Microbial oxidation of methane from old landfills in biofilters, Waste Manage., 23(7), 573-580, 2003.

Stuyfzand, P. J.: KIWA mededeling 89 Drinkwater uit oevergrondwater, Anorganische bestanddelen, 1985.

Stuyfzand, P. J.: De alkaliteit, het redoxniveau en de verontreinigingsindex als parameters en keuzemogelijkheden in een hydrochemische classificatie van watertypen, H2O 21 640-643, 1988.

Stuyfzand, P. J., Lüers, F., and Reijnen, G. K.: Geochemische aspecten van methaan in grondwater in Nederland, H2O 27, 500 510, 1994.

Stuyfzand, P. J. and Lüers, F.: KIWA mededeling 125. Gedrag van milieugevaarlijke stoffen bij oeverinfiltratie en kunstmatige infiltratie, 1996. 
Tekerlekopoulou, A. G., Vasiliadou, I. A., and Vayenas, D. V.: Physico-chemical and biological iron removal from potable water, Biochem. Eng. J., 31(1), 74-83, 2006.

van Dijk, J. C. and Wilms, D. A.: Water treatment without waste material. Fundamentals and state of the art of pellet softening, Aqua London, 40(5), 263-280, 1991.

Vandenabeele, J., Vande Woestyne, M., Houwen, F., Germonpre, R., Vandesande, D., and Verstraete, W.: Role of autotrophic nitrifiers in biological manganese removal from groundwater containing manganese and ammonium, Microb. Ecol., 29(1), 83-98, 1995.
VEWIN, Geudens P. J. J. G.: Waterleidingstatistiek 2007, Vewin nr. 2008/82/6259, http://www.vewin.nl/PUBLICATIES/ DRINKWATERSTATISTIEKEN/Pages/default.aspx, 2008. 